\title{
Ko

\section{Peranan Pramuwisata Dan Pemerintah Dalam Mencegah Pelecehan Kepariwisataan Budaya Bali}

\author{
A.A. Istri Eka Krisna Yanti \\ Universitas Dwijendra, Bali-Indonesia \\ anakagungistriekakrisnayanti@gmail.com
}

Published: 30/07/2020

How To Cite:

Yanti, A, A, I, E, K. (2020). Peranan Pramuwisata Dan Pemerintah Dalam Mencegah Pelecehan Kepariwisataan Budaya Bali. KERTHA WICAKSANA: Sarana Komunikasi Dosen dan Mahasiswa. 14 (2). Pp 77 - 86. https://doi.org/10.22225/kw.14.2.1863.77-86

\begin{abstract}
Abstrak
Bali adalah salah satu tujuan wisata paling populer di dunia. Model pariwisata yang dikembangkan di Bali adalah Wisata Budaya Bali yang didasarkan pada filosofi Tri Hita Karana yang merupakan sumber ajaran Hindu. Munculnya fenomena pemandu ilegal yang tidak bersertifikat dalam menjelaskan keunikan Wisata Budaya Bali, memiliki implikasi untuk pelecehan budaya Bali ke dalam latar belakang penulisan penelitian ini. Studi ini berfokus pada meneliti peran pemandu dan pemerintah dalam mencegah pelecehan terhadap Wisata Budaya Bali. Dalam penelitian ini, ada dua formulasi masalah yang dipelajari; apa prosedur sertifikasi kompetensi panduan di Provinsi Bali dan bagaimana pengawasan Panduan Pemerintah di Provinsi Bali. Metode penelitian yang digunakan dalam penelitian ini adalah metode penelitian normatif dengan fokus mempelajari legislasi dan literatur yang relevan dengan topik penelitian. Berdasarkan ketentuan Pasal 15 Peraturan Provinsi Bali Nomor 5 Tahun 2016 Tentang Pemandu Wisata, diketahui bahwa kewenangan pengawasan pemandu dimiliki oleh Gubernur Provinsi Bali yang dilakukan oleh departemen. Namun, ketentuan Pasal 15 (5) Peraturan Daerah Provinsi Bali Nomor 5 Tahun 2016 tentang Panduan menyebutkan bahwa Gubernur Provinsi Bali membentuk tim pemandu untuk melakukan pengawasan pemandu. Selanjutnya, Peraturan Provinsi Bali Nomor 5 Tahun 2016 Tentang Panduan tidak menjelaskan lebih lanjut mekanisme kerja tim pengawas, oleh karena itu pemerintah perlu membentuk peraturan yang lebih ketat terkait dengan pengawasan panduan untuk menjaga citra Wisata Budaya Bali dan memberikan perlindungan hukum untuk pemandu wisata bersertifikat di Provinsi Bali.
\end{abstract}

Kata kunci: Budaya bali, pariwisata, pemandu wisata, pemerintahan, pengawasan Abstract

Bali is one of the most popular tourist destinations in the world. The tourism model that is developed in Bali is Bali Cultural Tourism which is based on the philosophy of Tri Hita Karana which is the source of the teachings of Hinduism. The rise of the phenomenon of illegal guides who are not certified in explaining the uniqueness of Bali's Cultural Tourism, has implications for the harassment of Balinese culture into the background of the writing of this study. This study focuses on examining the role of guides and government in preventing harassment of the Bali Cultural Tourism. In this research, there are two problem formulations studied; what are the competency certification procedures of guides in the Province of Bali and how is the supervision of the Government Guide in the Province of Bali. The research method used in this study is a normative research method with a focus on studying the legislation and literature relevant to the research topic. Based on the provisions of Article 15 of the Bali Province Regulation Number 5 Year 2016 Regarding Tour Guides, it is known that the authority of guide supervision is owned by the Governor of Bali Province which is carried out by the department. However, the provisions of Article 15 (5) of Regional Regulation of the Province of Bali Number 5 of 2016 concerning Guides mentioned that the Governor of the Province of Bali formed a team of guides to carry out supervision of guides. Furthermore, Bali Provincial Regulation Number 5 Year 2016 About Guides does not explain further the work mechanism of the supervisory team, therefore the government needs to form more stringent regulations relating to the supervision of guides to maintain the image of Bali's Cultural Tourism and provide legal protection to Certified tour guide in Bali Province.

Keywords: Balinese culture, tourism, guides, government, supervision, 


\section{PENDAHULUAN}

The World Tourism Organization yang biasa disebut UNWTO sebagai organisasi pariwisata dunia menyebutkan, "The Travel and tourism industry is the world's largest and most diverse industri" (UNWTO, 1977). Pariwisata sebagai industri terbesar dan paling beragam dikembangkan diseluruh dunia sebagai bagian yang tidak terpisahkan dari kehidupan manusia menyangkut kegiatan sosial dan ekonomi. Dalam perkembangannya pariwisata hanya dinikmati oleh segelintir orang-orang yang relatif kaya, namun kini pariwisata telah menjadi bagian dari hak asasi manusia yang dapat dinikmati oleh setiap orang. Pengakuan hak berwisata sebagai bagian dari hak asasi manusia tertuang dalam bagian menimbang huruf $b$ Undang-Undang Nomor 10 Tahun 2009 tentang Kepariwisataan (selanjutnya disebut UU Kepariwisataan). Eksistensi pariwisata sebagai industri terbesar telah melahirkan sederet peluang dan tantangan bagi negaranegara yang bergantung pada industri pariwisata, termasuk Provinsi Bali, sebagai salah satu destinasi wisata yang paling popular di Indonesia.

Pariwisata tak ubahnya generator penggerak pembangunan perekonomian masyarakat Bali banyak orang yang beranggapan bahwa keindahan alam Bali merupakan daya tarik utama Pariwisata Bali. Pendapat demikian tidaklah salah, namun kurang tepat karena sesungguhnya daya tarik utama pariwisata Bali adalah kebudayan Bali yang selaras dengan keindahan alam Bali. Tjokora Oka Artha Ardana Sukawati dalam Webinar yang di selenggarakan Badan Penelitian dan Pegembangan Kabupaten Badung menyampaikan data statistik ketertarikan wisatawan ke Bali, 65\% Budaya Bali, 30\% Alam Bali dan 5\% atraksi buatan (Webinar, 2020). Kebudayaan Bali menempati posisi tertinggi sebagai daya tarik wisatawan. Pemerintah daerah Provinsi Bali menyadari betul bahwa kebudayaan Bali memegang peran penting dalam kepariwisataan Bali, maka Pemerintah Provinsi Bali menetapkan Peraturan Daerah
Provinsi Bali Nomor 2 Tahun 2012 Tentang Kepariwisataan Budaya Bali sebagai landasan utama pembangunan kepariwisataan Bali (selanjutnya disebut Perda Kepariwisataan Budaya Bali).

Kebudayaan Bali merupakan perwujudan cipta, rasa dan karsa masyarakat Bali, seperti seni tari, seni musik dan arsitektur yang bersinergi dengan ritual dan keagamaan masyarakat Hindu Bali yang menjadi daya tarik wisata tersendiri bagi wisatawan. Namun beberapa waktu belakangan ini banyak terjadi kasus yang dianggap pelecehan atas kebudayaan Bali yang dilakukan oleh para wisatawan, hal ini tidak saja merugikan citra pariwisata Bali, tetapi juga merugikan keseimbangan alam Bali secara niskala. Apabila ditelisik lebih jauh sesungguhnya pelecehan yang terjadi atas pariwisata budaya Bali terjadi atas kurangnya informasi atau pemahaman wisatawan atas kebudayaan tersebut.

UU Kepariwisataan menentukan bahwa setiap wisatawan berhak memperoleh informasi mengenai daya tarik wisata, untuk mendukung terealisasinya hak wisatawan tersebut maka berdasarkan ketentuan Pasal 23 UU Kepariwisataan pemerintah berkewajiban menyediakan informasi kepariwisataan dan wisatawan wajib menjaga dan menghormati norma agama, adat istiadat, budaya, dan nilainilai yang hidup dalam masyarakat setempat. Kunjungan wisatawan ke Bali tidak hanya ingin menikmati keindahan alam, tetapi juga ingin mengetahui sejarah lokasi yang dikunjugi (Fajar, 2015). Kasus-kasus pelecehan kepariwisataan Budaya Bali yang terjadi saat ini karena informasi yang diberikan tidak cukup jelas, salah satu contohnya kasus protesnya seorang wisatawan perempuan yang memposting pada akun sosial media miliknya 13 Maret 2020 lalu karena adanya larangan untuk masuk kepura bagi perempuan yang sedang menstruasi. Dalam postingannya perempuan tersebut menyebutkan bahwa larangan masuk ke Pura bagi perempuan yang sedang menstruasi adalah salah satu bentuk diskriminasi terhadap perempuan tidak perduli pada budaya, agama atau tradisi manapun. Dalam waktu sesaat postingan tersebut viral keseluruh dunia yang memberikan citra citra negatif pada pariwisata Budaya Bali. Dalam keadaan ini, pemerintah dapat dikatakan gagal memberikan 
informasi kepariwisataan sehingga wisatawan tidak mendapatkan informasi yang akurat mengenai daya tarik wisata.

Larangan masuk kepura tersebut sesungguhnya tidak hanya berlaku bagi wisatawan, tapi sesungguhnya berlaku bagi umat perempuan hindu sendiri, kerena pada masa menstruasi perempuan dianggap cuntaka atau dalam keadaan yang tidak suci menurut kepercayaan umat Hindu di Bali. Keadaan cuntaka sesungguhnya tidak hanya terjadi bagi perempuan yang menstruasi tetapi juga bagi umat Hindu apabila terdapat kematian, persalinan, keguguran dan kondisi-kondisi lainnya yang perlu disucikan dengan upacara keagamaan. Selain kasus pelecehan tersebut, terdapat banyak kasus pelecehan kepariwisaatan budaya Bali yang menyebabkan masyarakat Hindu di Bali harus melakukan upacara agama untuk kembali mensucikan alam di Bali yang tentunya sangat merugikan secara materil dan inmateriil. Kasus pelecehan terhadap kepariwisatan budaya Bali ini sesungguhnya dapat dihindari jika terjadi sinergi yang baik antara kewajiban pemerintah dalam menyediakan informasi kepariwisataan, sehingga dapat terpenuhi hak wisatawan atas informasi yang akurat mengenai daya tarik wisata agar wisatawan dapat melaksanakan kewajibannya untuk menjaga dan menghormati budaya Bali sebagaimana amat yang terdapat dalam UU Kepariwisataan.

Dalam upaya menyediakan informasi mengenai kepariwisataan pemerintah telah berupaya dengan memasang informasi dibeberapa daya tarik wisata, namun belajar dari kasus-kasus yang telah terjadi hal tersebut dirasa masih kurang efektif sehingga sangat diperlukan peran pramuwisata dalam memberikan infomasi mengenai daya tarik wisata. Ketentuan mengenai Pramuwisata di Provinsi Bali diatur secara khusus dalam Peraturan Daerah Provinsi Bali Nomor 5 Tahun 2016 Tentang Pramuwisata (selanjutnya disebut Perda Pramuwisata). Dalam Perda Pramuwisata, pramuwisata didefiniskan sebagai Warga Negara Indonesia yang bertugas memberikan bimbingan, penerangan, dan petunjuk mengenai daya tarik wisata serta membantu segala sesuatu yang diperlukan wisatawan. Ketentuan status kewarganegaraan Indonesia bagi pramuwisata bukan tanpa alasan, karena dalam melaksanakan tugasnya pramuwisata harus memahami nilai-nilai luhur kebudayaan Indonesia terlebih di Bali yang mengedepankan Kepariwisataan Budaya Bali sebagai

landasan

utama

pengembangan

kepariwisataannya. Dalam ketentuan Pasal 4 Perda Pramuwisata bahkan mensyaratkan surat keterangan bertempat tinggal/domisili di Kabupaten/Kota di wilayah Provinsi paling singkat 2 (dua) tahun yang dibuktikan dengan surat keterangan dari Kepala Desa/Kelurahan bagi masyarakat yang mengajukan permohonan untuk menjadi pramuwisata.

Dalam ketentuan Perda Pramuwisata, pramuwisata di wilayah hukum Provinsi Bali diwajibkan memiliki Sertifikat Lulus Uji Pengetahuan Budaya Bali sebagai bukti kelayakan kompetensi untuk menerangkan Kebudayaan Bali kepada wisatawan, sehingga dapat menghindari kesalahan pahaman atas budaya Bali yang berujung pada pelecehan kebudayaan Bali. Namun kini banyak bermunculan Pramuwisata Ilegal yang bahkan berwarga negara asing medampingi wisatawan sehingga tidak mampu memberikan cukup pengetahuan atas kepariwisataan budaya bali yang landasakan ajaran Agama Hindu, falsafah Tri Hita Karana. Hal inilah yang menjadi salah satu faktor maraknya kasus pelecehan Kebudayaan Bali yang dilakukan oleh wisatawan untuk itu diperlukan sinergi antara pemerintah dan pramuwisata dalam menjaga "keajengan" budaya Bali.

Berdasarkan latar belakang masalah yang telah dipaparkan diatas, maka terdapat 2 (dua) rumusan permasalahan yang akan dikaji lebih dalam yaitu; bagaimanakah prosedur sertifikasi kompetensi pramuwisata Provinsi Bali dan bagaimanakah pengawasan Pemerintah terhadap Pramuwisata di Provinsi Bali.

\section{METODE}

Dalam penelitian ini, peneliti menggunakan jenis penelitian normatif. Menurut Soejono Soekanto penelitian hukum normatif merupakan penelitian hukum yang dilakukan dengan cara meneliti bahan pustaka. Penelitian hukum normatif atau kepustakaan mencakup: penelitian terhadap asas-asas hukum, penelitian terhadap sistematika hukum, penelitian terhadap tahap sinkronisasi vertikal dan horizontal, perbandingan hukum serta sejarah hukum (Soekanto \& Mamudji, 2001). Jenis penelitian ini dipilih karena terdapat kekaburan norma dalam pengawasan pramuwisata. Dalam Perda Pramuwisata tidak ditentukan dengan jelas pihak yang diberikan kewenangan untuk melaksanakan pengawasan kepada pramuwisata. Jenis 
pendekatan yang digunakan dalam penelitian ini adalah the statute approach, sesuai dengan karakteristik penelitian normatif. The statute approach atau pedekatan perundang-udangan yakni beberapa penelusuran terhadap peraturan perundang-undangan yang terkait dengan peranan pramuwisata dan pemerintah dalam mencengah pelecehan kepariwisataan budaya Bali. Bahan hukum yang digunakan dalam penelitian ini terdiri dari 2 (dua) jenis bahan hukum yaitu bahan hukum primer yang terdiri dari peraturan perundangan-undangan yang dianalisi sesuai dengan hirarkienya dan bahan hukum sekunder yaitu bahan-bahan yang memiliki banyak korelasi dengan bahan hukum primer serta berfungsi untuk membantu dalam menganalisa dan memahami bahan hukum primer. Adapun bahanbahan sekunder berupa publikasi tentang hukum. Publikasi tentang hukum meliputi buku-buku teks, kamus-kamus hukum, jurnal-jurnal hukum dan komentar-komentar atas putusan pengadilan (Marzuki, 2013). Teknik pengumpulan bahan hukum yang dilakukan dengan melakukan study dokumen. Teknik analisis bahan hukum yang diperoleh terkait dengan permasalahan yang dibahas selanjutnya dianalisis melalui langkahlangkah deskripsi, interprestasi, sistematisasi, evaluasi dan argumentasi.

\section{III.HASIL DAN PEMBAHASAN}

\section{Prosedur Sertifikasi Kompetensi Pramuwisata Provinsi Bali}

Bali merupakan destinasi pariwisata terpopuler di Indonesia. Kepala BPS Provinsi Bali, Adi Nugroho menyampaikan kenaikan jumlah kunjungan wisatawan di Provinsi Bali naik sebesar 3.7\% atau sebanyak 6.275 .210 orang pada tahun 2019 (www.nusabali.com, 2019). Kenaikan jumlah kunjungan wisawatan ke Provinsi Bali bukan semata-mata hanya karena pesona keindahan alam Bali tapi pada keunikan kebudayaan Bali yang menjadi landasan utama pembangunan kepariwisataan Budaya Bali. Dalam mendukung citra kepariwisataan budaya Bali, diperlukan pramuwisata yang memiliki kompetensi yang telah tersertifikasi sehingga dapat menjaga citra keunikan pariwisata Bali.

Secara hierarki, sertifikasi kompetensi pramuwisata diatur dalam ketentuan Pasal 53 UU Kepariwisataan yang menyebutkan sebagai berikut;

Tenaga kerja di bidang kepariwisataan memiliki standar kompetensi.
Standar kompetensi sebagaimana dimaksud pada ayat (1) dilakukan melalui sertifikasi kompetensi.

Sertifikasi kompetensi dilakukan oleh lembaga sertifikasi profesi yang telah mendapat lisensi sesuai dengan ketentuan peraturan perundangundangan.

Sertifikasi dalam ketentuan UU Kepariwisataan di definisikan sebagai proses pemberian sertifikat kepada usaha dan pekerja pariwisata untuk mendukung peningkatan mutu produk pariwisata, pelayanan, dan pengelolaan kepariwisataan. Sertifikasi kompetensi diberikan oleh lembaga sertifikasi profesi yang mendapat lisensi dari Badan Nasional Sertifikasi Profesi. Sertifikat diberikan kepada pramuwisata yang telah lulus uji kompetensi sebagaimana yang ditentukan dalam peraturan perundang-undangan. Uji kompetensi dilakukan berdasarkan standar kompetensi yang disusun bersama-sama oleh instansi pemerintah di bidang pariwisata, asosiasi pariwisata, pengusaha, dan akademisi. UU Kepariwisataan tidak mengatur lebih jauh mengenai Sertifikasi Kompetensi, namun dalam Pasal 55 Kepariwisataan disebutkan bahwa sertifikasi kompetensi akan diatur lebih lanjut dalam Peraturan Pemerintah.

Dua tahun setelah disahkannya UU Kepariwisataan, pengaturan sertifikasi usaha pariwisata diatur dalam Peraturan Pemerintah No. 52 Tahun 2012 Tentang Sertifikasi Kompetensi Dan Sertifikasi Usaha Di Bidang Pariwisata (selanjutnya disebut PP Sertifikasi Kompetensi dan Usaha Pariwisata). Sertifikasi Kompetensi di Bidang Pariwisata adalah proses pemberian sertifikat kompetensi di bidang kepariwisataan yang dilakukan secara sistematis dan objektif melalui uji kompetensi sesuai Standar Kompetensi Kerja Nasional Indonesia, standar internasional dan/atau standar khusus. Sertifikasi Kompetensi di Bidang Pariwisata, bertujuan untuk memberikan pengakuan terhadap Kompetensi yang dimiliki tenaga kerja dan meningkatkan kualitas dan daya saing tenaga kerja.

Dalam pemberian sertifikasi kompetensi dibidang kepariwisataan diperlukan adanya suatu standar sebagai tolak ukur penetapan kompetensi. Pasal 17 PP Sertifikasi Kompetensi dan Usaha Pariwisata disebutkan bahwa pramuwisata sebagai salah satu jenis usaha dibidang jasa pariwisata yang berkewajiban menerapkan standar dalam usaha pariwisata. Standar Usaha 
Pariwisata adalah rumusan kualifikasi usaha pariwisata dan/atau klasifikasi usaha pariwisata yang mencakup aspek produk, pelayanan, dan pengelolaan usaha pariwisata yang dibuktikan secara tertulis dengan Sertifikat Usaha Pariwisata. Dalam Pasal 18 PP Sertifikasi Kompetensi dan Usaha Pariwisata disebutkan bahwa pengaturan lebih lanjut mengenai Standar Usaha Pramuwisata diatur dalam Peraturan Menteri.

Menyikapi amanat Pasal 18 PP Sertifikasi Kompetensi dan Usaha Pariwisata, Pada tanggal 1 September 2015 Menteri Pariwisata Republik Indonesia menetapkan Peraturan Menteri Pariwisata Nomor 13 Tahun 2015 Tentang Standar Usaha Jasa Pramuwisata. Standar Usaha Jasa Pramuwisata berisikan rumusan kualifikasi dan/atau klasifikasi yang mencakup aspek produk, pelayanan dan pengelolaan Usaha Jasa Pramuwisata. Pasal 5 ayat (1) Permen Standar Usaha Pariwisata mewajibkan setiap usaha Jasa Pramuwisata untuk memilki sertifikat.

Pada tingkat Provinsi, pengaturan Pramuwisata diatur secara khusus dalam Perda Pramuwisata menggantikan Peraturan Daerah Provinsi Bali Nomor 5 Tahun 2008 tentang Pramuwisata yang sudah tidak lagi sesuai dengan kondisi dan kebutuhan hukum saat ini. Pramuwisata secara sederhana bertugas memberikan petunjuk tentang suatu obyek wisata (Ismayanti, 2010). Selain memberikan pentunjuk, Menurut I Ketut Ardana pramuwisata juga berkewajiban memberikan bimbingan, penerangan dan berbagai pelayanan kepada para wisatawan (Ardana, 2013). Dalam ketentuan Pasal 9 ayat (1) Perda Pramuwisata secara lebih rinci menguraikan kewajiban Pramuwisata dalam kepemanduan wisatawan meliputi:

Mengantarkan wisatawan, baik rombongan maupunperorangan yang mengadakan perjalanan dengan transportasi yang tersedia;

Memberikan penjelasan dan petunjuk tentang rencana perjalanan, DTW serta memberikan penjelasan mengenai dokumen perjalanan, akomodasi, transportasi dan fasilitas wisatawan lainnya;

Membantu menguruskan barang bawaan wisatawan dan membantu keperluan wisatawan lainnya;dan

Memberikan pertolongan kepada wisatawan yang sakit, mendapatkan kecelakaan, kehilangan atau musibah lainnya.
Dalam menjalankan kewajiban kepemanduan wisata, pramuwisata diwajibkan mengenanakan Pakaian Adat Bali sebagai perwujudkan Kepariwisataan Budaya Bali. Namun, dalam pelaksanaanya pramuwisata diberikan pengecualian dalam mengenakan Pakaian Adat Bali apabila Pramuwisata menjalankan tugas kegiatan wisata tirta, pendakian, lintas alam dan perkemahan.

Dalam hal memberikan bimbingan dan penerangan kepada wisatawan pramuwisata diwajibkan untuk memenuhi hak wisatawan yaitu mendapatkan informasi yang akurat mengenai daya tarik wisata sehingga wisatawan dapat melaksanakan kewajibannya sebagai wisatawan. Menurut ketentuan Pasal 25 UU Kepariwisataan, kewajiban wisatawan dirumuskan sebagai berikut;

Menjaga dan menghormati norma agama, adat istiadat, budaya, dan nilai-nilai yang hidup dalam masyarakat setempat;

Memelihara dan melestarikan lingkungan;

Turut serta menjaga ketertiban dan keamanan lingkungan; dan

Turut serta mencegah segala bentuk perbuatan yang melanggar kesusilaan dan kegiatan yang melanggar hukum.

Apabila wisatawan melanggar ketentuan kewajibannya sebagaimana ketentuan Pasal 25 UU Kepariwisataan dan justru melakukan pelecehan atas budaya Bali, maka berdasarakan ketentuan Pasal 62 UU Kepariwisataan wisatawan dapat diberikan sanksi administratif berupa teguran lisan disertai dengan pemberitahuan mengenai hal yang harus dipenuhi dan jika tidak diindahkan maka wisatawan yang bersangkutan dapat diusir dari lokasi perbuatannya dilakukan. Hal ini tentu saja peristiwa yang sangat tidak menyenangkan bagi wisatawan dan pramuwisata merupakan pihak yang berperan penting dalam memberikan informasi, mengdampingi, mengedukasi wisatawan agar dapat menghormati kepariwisataan budaya Bali. Hal ini tentu saja hanya dapat terjadi apabaila pramuwisata tersebut telah tersertifikasi, namun kini banyak dijumpai pramuwisata ilegal yang tidak mampu menjelaskan keunikan kepariwisataan budaya bali.

Pramuwisata ilegal adalah mereka yang tidak memiliki sertifikasi kompetensi sebagaimana 
yang ditetapkan peraturan perundang-udangan. Dasar pelaksanaan sertifikasi kompetensi pramuwisata Provinsi Bali diatur dalam Perda Pramuwisata yang dengan tegas menentukan bahwa pramuwisata wajib memiliki Kartu Tanda Pengenal Pramuwisata (KTPP) untuk dapat melaksanakan tugas kepemanduan wisata. Meskipun KTPP hanyalah kartu pengenal, sertifikasi kompetensi pramuwisata dapat dilihat dari KTPP. KTPP dapat dikatakan sebagai luaran akhir dari proses sertifikasi yang dilakukan oleh pramuwisata, salah satu syarat untuk mendapatkan KTPP pramuwisata harus lulus Uji Pengetahuan tentang Budaya Bali yang diuji oleh tim penguji. Adapun rincian persyaratan mengajukan KTPP yang meliputi;

Surat Permohonan Mengajukan KTPP kepada Gubernur Cq. Kepala Dinas Pariwisata Provinsi Bali.

Warga Negara Indonesia yang dibuktikan dengan foto copy KTP.

Melampirkan surat keterangan bertempat tinggal/domisili di wilayah Provinsi Bali paling singkat 2Tahun.

Berusia sekurang-kurangnya 19 (sembilan belas) tahun atau sudah menikah;

Melampirkan foto copy Sertifikat Kompetensi Kepemanduan Wisata;

Melampirkan foto copy Sertifikat Lulus Uji Pengetahuan tentang Budaya Bali oleh Tim Penguji.

Pendidikan serendah-rendahnya Sekolah Menengah Atas/sederajat dan/atau mempunyai pengalaman magang paling singkat 2 (dua) tahun sebagai Pramuwisata pada Biro Perjalanan Wisata di Provinsi yang dibuktikan dengan surat rekomendasi dari Asosiasi Biro Perjalanan Wisata;

Surat keterangan bebas narkoba;

Surat keterangan sehat dari pusat kesehatan masyarakat/rumah sakit pemerintah;dan

surat keterangan catatan kepolisian..

Pramuwisata yang telah memiliki KTPP diharuskan terhimpun dalam suatu organisasi kepariwisataan atau dapat tergabung dalam usaha jasa pariwisata hal ini bertujuan untuk mengorganisir kegiatan kepemanduwisataan. Pramuwisata tidak dapat bekerja secara bebas dilapangan tanpa terikat dalam suatu organisasi ataupun jasa. KTPP memiliki jangka waktu selama 3 (tiga) tahun dan dapat diperpanjang kembali paling lambat 1(satu) bulan sebelum masa berlakunya berakhir. Dalam hal perpanjangan KTPP, pramuwisata harus mengajukan permohonan kepada Gubernur dengan melampirkan kembali Sertifikat Kompetensi Kepemanduan Wisata.

\section{Pengawasan Pemerintah Terhadap Pramuwisata di Provinsi Bali}

Pengawasan merupakan suatu istilah yang dalam banyak hal memiliki arti sama dengan istilah kontrol. Dalam Kamus Umum Bahasa Indonesia kata kontrol adalah pengawasan, pemeriksaan (kbbi.kemdikbud.go.id). Pengawasan dalam arti sempit dapat definisikan sebagai segala usaha atau kegiatan untuk mengetahui dan menilai kenyataan yang sebenarnya tentang pelaksanaan tugas atau pekerjaan apakah sesuai dengan semestinya atau tidak. Dalam perspektif hukum administrasi negara pengawasan diperlukan untuk menjamin pelaksanaan penyelengaraan pemerintah berjalan sesuai dengan ketentuan peraturan perundanganundangan sehingga dapat mencapai tujuan dibentuknya suatu norma hukum tersebut. Pengawasan pemerintah terhadap pramuwisata bertujuan untuk memberikan penerangan dan bimbingan serta petunjuk kepada wisatawan mengenai daya tarik wisata dengan baik sehingga wisatawan dapat menghormati norma agama, adat istiadat, budaya, masyarakat Hindu di Bali.

Menurut kententuan Pasal (2) ayat (1) Instruksi Presiden Nomor 15 Tahun 1983 Tentang Pedoman Pelaksanaan Pengawasan menyebutkan bahwa pengawasan terdiri atas:

Pengawasan yang dilakukan oleh pemimpin atasan langsung baik di tingkat pusat maupun di tingkat daerah.

Pengawasan yang dilakukan secara fungsional oleh aparat pengawasan. Pengawasan fungsional bertujuan untuk membantu pimpinan dalam menjalankan fungsi pengawasan dilingkungan organisasi yang menjadi tanggung jawabnya.

Dalam melaksanakan pengawasan dibutuhkan instrumen pemerintahan atau alat-alat yang digunakan oleh pemerintah administrasi negara dalam melaksanakan tugasnya (Ridwan, 2008). Pemerintah juga menggunakan instrumen yuridis dalam menjalankan kegiatan mengatur dan menjalanan urusan pemerintahan dan kemasyarakatan yaitu dengan instrumen 
perijinan. Menurut Sjachran Basah, izin adalah perbuatan hukum administrasi Negara bersegi satu yang mengaplikasikan peraturan dalam hal konkret berdasarkan persyaratan dan prosedur sebagaimana ditetapkan oleh ketentuan peraturan perundang-undangan.

KTPP memiliki makna lebih dari sekedar identitas bagi pramuwisata, KTPP adalah bukti izin kepemanduan wisata dan sertifikasi kompetensi yang dimiliki oleh pramuwisata. Dalam Pasal 29 huruf c UU Kepariwisataan menentukan bahwa pemerintah provinsi berwenang dalam melaksanakan pendaftaran, pencatatan dan pendataan usaha pariwisataan termasuk usaha jasa pramuwisata. Merujuk pada UU Kepariwisataan tersebut, Pasal 14 ayat (1) Permen Standar Usaha Jasa Pramuwisata mementukan bahwa pengawasan pramuwisata dilaksanakan oleh Menteri, Gubernur, dan Bupati/ Walikota melakukan pengawasan penerapan dan pemenuhan Standar sesuai kewenangannya. Adapun rinciannya sebagai berikut:

Pengawasan yang dilakukan oleh Menteri melalui evaluasi penerapan Standar.

Pengawasan yang dilakukan oleh Gubernur melalui evaluasi laporan kegiatan penerapan Standar di wilayah kerja.

Bupati/Walikota melakukan pengawasan melalui evaluasi terhadap persyaratan dasar, dan kepemilikan Sertifikat.

Lebih lanjut, dalam ketentuan Perda Pramuwisata kewenangan pengawasan Pramuwisata diatur sebagai berikut;

Gubernur melaksanakan pengawasan terhadap Pramuwisata.

Gubernur dalam pengawasan Pramuwisata berkoordinasi dengan Bupati/Walikota.

Pengawasan terhadap Pramuwisata dilaksanakan oleh Dinas.

Gubernur membentuk Tim untuk melaksanakan pengawasan yang ditetapkan dengan Keputusan Gubernur.

Dalam arti yuridis Indroharto menyebutkan bahwa kewenangan adalah kemampuan yang diberikan oleh peraturan perundanganperundangan untuk menimbulkan akibat hukum. Sementara itu Henc van Maarseveen sebagaimana dikutip Philipus M. Hadjon mengatakan didalam hukum publik, wewenang sekurang-kurangnya terdiri dari tiga komponen yaitu :

komponen pengaruh, ialah bahwa penggunaan wewenang dimaksudkan untuk mengendalikan perilaku subyek hukum;

komponen dasar hukum, bahwa wewenang itu selalu harus dapat ditunjuk dasar hukumnya; dan

komponen konformitas hukum, mengandung makna adanya standard wewenang, baik standard umum (semua jenis wewenang) maupun standard khusus (untuk jenis wewenang tertentu) (Sadjijono, 2008).

Philipus M. Hadjon juga mendeskripsikan kewenangan sebagai kekuasaan hukum atau (bevoegdheid) atau rechtmacht. Jadi dalam konsep hukum publik, wewenang berkaitan dengan kekuasaan.

Berdasarkan ketentuan Pasal 3 Perda Pramuwisata Provinsi Bali KTPP diterbitkan oleh Gubernur dengan menunjuk Kepala Dinas. Kepala Dinas yang ditunjuk dalam kompetensi ini adalah Kepala Dinas Prariwisata Provinsi Bali. Gubernur sebagai organ pemerintah yang ditunjuk menerbitkan KTPP juga diberikan kewenangan untuk melaksakan pengawasan terhadap pramuwisata. Kewenangan yang dimiliki oleh Gubernur dalam menerbitkan KTPP dan pengawasan pramuwisata merupakan kewenangan yang diperoleh secara atribusi. Atribusi merupakan kewenangan yang didapat oleh organ pemerintah adalah kewenangan asli, karena kewenangan tersebut diperloleh langsung oleh peraturan perundang-undangan (Suparta, 2013).

Dalam menjalankan perannya Gubernur memiliki 3 (tiga) peran/fungsi dalam penyelenggaraan pemerintahan yaitu; Gubernur sebagai kepala daerah otonom, Gubernur sebagai wakil Pemerintah di daerah, dan Gubernur sebagai "wakil" Presiden dalam menyelenggarakan urusan pemerintahan umum (Prihatiningtyas, 2017). Dalam hal penyelenggaraan pemerintahan didaerah Gubernur dapat menujuk atau mendelegasikan tugasnya, terkait pengawasan pramuwisata menurut ketentuan Pasal 15 ayat (4) Perda Pramuwisata pelaksanaan pengawasan pramuwisata dilaksanakan oleh Dinas sedangkan, ketentuan Pasal 15 ayat (5) menentukan bahwa Gubernur membentuk Tim untuk melaksanakan pengawasan pramuwisata yang ditetapkan dengan Keputusan Gubernur. Dalam ketentuan Pasal 15 ayat (2) juga disebutkan bahwa dalam 
melaksanakan pengawasan berkordinasi dengan Bupati atau Walikota. Hal inilah yang menjadi kekaburan norma dalam hal pengawasan pramuwisata. Ketentuan Perda Pramuwisata pada akhirnya tidak menjelaskan siapa menjadi pelaksana dalam pengawasan pramuwisata. Perda Pramuwisata juga tidak menjelaskan lebih lanjut tanggung jawab, mekanisme kerja serta siapa saja yang menjadi bagian dari tim tersebut, berbeda dengan Tim Penguji Sertifikasi yang ditentukan dalam Perda Pramuwisata secara sangat terperinci.

Pengawasan terdiri dari beberapa jenis salah satunya adalah pengawasan preventif dan represif. Pengawasan jenis ini dilaksanakan berkaitan dengan waktu pelaksanaan pengawasan. Pengawasan preventif merupakan pengawasan yang dilakukan sebelum pelaksanaan kegiatan sehingga diharapkan dapat mencengah terjadinya penyimpangan atas ketentuan perundangundanganan. Sedangkan pengawasan represif merupakan pengawasan yang dilakukan setelah terjadinya suatu kegiatan.Sejalan dengan dua jenis penarapan tersebut, Ridwan HR berpendapat dalam Hukum Administrasi terdapat dua sarana penegakan hukum yaitu pengawasan dan penerapan sanksi oleh organ pemerintahan (Ridwan, 2008). Pengawasan merupakan langkah preventif untuk memaksakan kepatuhan, sedangkan penerapan sanksi merupakan merupakan langkah represif untuk memaksakan kepatuhan.

Secara eksplisif maupun implisif yang membedakan norma hukum dengan norma lainnya adalah pada norma hukum dilekatkan suatu paksaan atau sanksi (Marzuki, 2013). Henry Campbell Black merumuskan sanksi sebagai "that part of a law which is designed to secure enforcement by imposing a penalty for its violation or offering a reward for its observance". (Bagian dari hukum yang dirancang untuk mengamankan penegakan hukum dengan menjatuhkan hukuman atas pelanggarannya atau menawarkan ganjaran atas ketaatannya) (Susanto, 2019). Sanksi merupakan salah satu bentuk pengawasan represif untuk memastikan pengaturan atas pramuwisata berjalan sesuai dengan prosedur yang ditetapkan oleh peraturan perundang-undangan. Indonesia merupakan negara hukum yang memiliki kewenangan menggunakan "daya paksa" berupa penghukuman legal (Atmaja, 2013).

Kewenangan (bevoegdheid) dideskripsikan sebagai kekuasaan hukum atau rechtmacht. Dalam konsep hukum publik wewenang berkaitan dengan dengan kekuasaan. Kekuasaan mutlak dibutuhkan dalam kelangsungan pergaulan hidup antar manusia, atau juga untuk mencapai tujuantujuan dari pendirian suatu Negara (Mangunsong, 2002). Adapun tujuan dari dilaksanakannya pengawasan terhadap pramuwisata sebagai berikut;

Untuk mengetahui apakah kepemanduan pariwisata berjalan sesuai dengan rencana yang telah ditetapkan.

Untuk mengetahui apakah kepemanduan pariwisata telah berjalan sesuai dengan instruksi serta prinsip-prinsip yang telah ditetapkan.

Untuk mengetahui apakah kelemahankelemahan sehingga dapat dilakukan pembaharuan.

Lemahnya pengawasan terhadap pramuwisata selain merugikan citra pariwisata Bali juga sangat merugikan para pramuwisata yang telah bersertifikasi. Pada tahun 2018, menurut Ketua Himpunan Pramuwisata Indonesia (HPI) Bali I Nyoman Winastra terdapat sekitar 300 pramuwisata ilegal (https://bali.bisnis.com). Sedangkan jumlah pramuwisata yang terdaftar pada Himpunan Pramuwisata Indonesia di Bali saat ini berjumalh 3508 orang yang tergabung dalam sebelas devisi bahasa. Adapun rincian jumlah keanggotaan pramuwisata di Bali sebagai berikut;

\begin{tabular}{lll}
\hline No & $\begin{array}{l}\text { Devisi } \\
\text { Bahasa }\end{array}$ & $\begin{array}{l}\text { Jumlah } \\
\text { Pramuwisata }\end{array}$ \\
\hline 1 & Belanda & 67 \\
2 & Inggris & 591 \\
3 & Itali & 57 \\
4 & Jepang & 501 \\
5 & Indonesia/ & 838 \\
& Melayu & \\
6 & Jerman & 180 \\
7 & Korea & 467 \\
8 & Mandarin & 482 \\
9 & Perancis & 191 \\
10 & Rusia & 74 \\
11 & Spayol & 60 \\
\hline
\end{tabular}

Pengawasan represif mutlak diperlukan untuk mengatasi marakanya pramuwisata ilegal di provinsi Bali tidak hanya merugikan citra kepariwisataan Bali tetapi juga merugikan pramuwisata bersertifikasi untuk diperlukan penghukuman tegas bagi pramuwisata ilegal. I 


Dewa Gede Atmaja mendefinisikan
penghukuman legal dimaksudkan sebagai pembenaran pengenaan hukuman atau sanksi pidana dengan memiliki dasar pembenar baik secara yuridis maupun secara etika. Dasar penghukuman pramuwisata berdasarkan ketentuan Pramuwisata terbagi menjadi 2 jenis sanksi, yaitu sanki administratif dan sanksi pidana. Penerapan saksi administratif dalam suatu hubungan hukum antara pemerintah dan masyarakat merupakan salah satu bentuk dari tindakan pemerintah yang dilakukan dalam rangka penegakan hukum administrasi. Sanksi administrasi dalam Perda Pramuwisata diberikan kepada mereka yang melanggar ketentuan sebagai berikut;

KTPP yang dimiliki telah jatuh tempo dan tidak diperpanjang.

Tidak melakukan kewajiban pramuwisata dalam kepemanduan wisatawan yang meliputi;

Mengantarkan wisatawan, baik rombongan maupun perorangan yang mengadakan perjalanan dengan transportasi yang tersedia;

Memberikan penjelasan dan petunjuk tentang rencana perjalanan, DTW serta memberikan penjelasan mengenai dokumen perjalanan, akomodasi, transportasi dan fasilitas wisatawan lainnya;

Membantu menguruskan barang bawaan wisatawan dan membantu keperluan wisatawan lainnya;dan

Memberikan pertolongan kepada wisatawan yang sakit, mendapatkan kecelakaan, kehilangan atau musibah lainnya (Pasal 9 ayat (1) Perda Pramuwisata).( Pasal 9 ayat (1) Perda Pramuwisata)

Tidak menaati agenda perjalanan yang telah disepakati dengan wisatawan.

Tidak mengenakan pakaian adat bali saat bertugas (terdapat pengecualian apabila menjalankan tugas wisata tirta, pendakian, lintas alam dan perkemahan.)

Adapun jenis sanksi yang atas pelanggaran tersebut sebagai berikut:

\section{Teguran lisan;}

Sanksi teguran yang dinyatakan dan disampaikan secara lisan oleh pejabat yang berwenang menghukum kepada pramuwisata yang melakukan kesalahan.
Teguran tertulis;

Sanksi teguran tertulis dinyatakan dan disampaikan secara tertulis oleh pejabat yang berwenang. Sanksi ini merupakan tindak lanjut atas sanksi terguran lisan yang apabila dalam jangka waktu 6 (enam) bulan sejak teguran lisan diberikan pramuwisata melakukan kesalahan yang sama.

\section{Pembekuan KTPP}

Sanksi pembekuan KTPP merupakan pencabutan sementara KTPP Pramuwisata yang bersangkutan selama 3 (tiga) bulan dan setelah masa pembekuannya berakhir KTPP Pramuwisata tersebut dikembalikan untuk dapat kembali melaksanakan tugas kepemanduan sebagaimana biasa.

\section{Pencabutan KTPP.}

Pencabutan KTPP merupaka pengambilan KTPP pramuwisata yang bersangkutan oleh pejabat yang berwenang apabila pramuwisata tersebut sudah pernah dijatuhi sanksi teguran lisan, teguran tertulis dan pembekuan KTPP. Apabila pramuwisata yang bersangkutan ingin mendaftarkan diri kembali sebagai pramuwisata maka harus mengikuti tahap pendaftaran pramuwisata sesuai peraturan yang berlaku untuk mendapatkan KTPP baru.

Selain menerapkan sanksi administratif, Perda Pramuwisata juga menerapkan sanksi pidana terhadap pramuwisata yang melakukan pelanggaran dengan tidak memiliki KTPP dalam melaksanakan tugas kepemanduan wisata. Pelanggaran terhadap kewajiban memiliki KTPP bagi pramuwisata diancam dengan pidana kurungan paling lama 3 (tiga) bulan atau denda paling banyak Rp. 50.000.000 (lima puluh juta rupiah).

\section{IV.SIMPULAN}

Dari yang telah disampaikan sebelumnya dapat disimpulkan yaitu KTPP merupakan kartu tanda identitias bagi pramuwisata yang dapat membuktikan sertifikasi kompetensi pramuwisata karena satu persyaratan Pengajuan KTPP, harus melampirkan sertifikat lulus ujian kompetensi yang diujikan oleh Tim Penguji. Pramuwisata yang tidak memiliki KTPP dapat dikatakan sebagai pramuwisata illegal yang tidak memiliki kompetensi dalam melakukan kegiatan kepemanduan wisata. Dalam Perda Pramuwisata disebutkan bahwa KTPP diterbitkan oleh Gubernur yang dalam pelaksanaanya tugas 
tersebut didelegasikan kepada Dinas Pariwisata Provinsi Bali.

Pengawasan Pramuwisata merupakan hal yang mutlak untuk dilakukan sebagai upaya menjaga citra pariwisata Bali. Berdasarkan ketentuan Perda Pramuwisata terjadi kekaburan norma atas pihak yang berwenangan melakukan pengawasan Pramuwisata dalam ketentuan Pasal 15 Perda Pramuwisata disebutkan bahwa kewenangan pelaksanaan pengawasan berada pada Gubernur yang pelaksanaanya dilaksanakan oleh dinas. Namun pada Pasal 15 ayat (5) Perda Pramuwisata disebutkan bahwa Gubernur membentuk Tim yang ditetapkan dengan Keputusan Gubernur untuk melaksanakan pengawasan terhadap pramuwisata. Namun, dalam ketentuan Perda Perda Pramuwisata tidak ditentukan lebih lanjut mengenai ketentuan dan mekanisme kerja Tim pengawas pramuwisata tersebut.

\section{DAFTAR PUSTAKA}

Ardana, I. K. (2013). Menjadi Pramuwisata Profesinal. Denpasar: Tabur Kata Publishing.

Atmaja, I. D. G. (2013). Filsafat Hukum Dimensi Tematis dan Historis. Malang: Setara Press.

Fajar, N. M. A. P. (2015). Pelaksanaan Peraturan Daerah Provinsi Bali No 5 Tahun 2008 Tentang Pramuwisata Di Kabupaten Badung. Jurnal Magister Hukum Udayana (Udayana Master Law Journal), 4(2), 14. Retrieved from https:// ojs.unud.ac.id/index.php/jmhu/article/ view/17538

https://bali.bisnis.com/read/20180411/538/782932/biro -wisata-bali-segera-bentuk-satgas-pengawasanpekerja-wisata-asing,diakses pada 28 Mei 2020.

https://kbbi.kemdikbud.go.id/entri/kontrol, diakses pada 20 Mei 2020.

https://www.nusabali.com/berita/68256/62-jutawisman-kunjungi-bali-pada-2019, diakses pada 28 Mei 2020.

Ismayanti. (2010). Pengantar Pariwisata. Jakarta: PT. Gramedia Widiasarana Indonsia.

Mangunsong, P. M. (2002). Pembatasan Kekuasaan Melalui Hukum Administrasi Negara dalam Dimensi-Dimensi Pemikiran Hukum Administrasi Negara. Yogyakarta: UII Press.

Marzuki, P. M. (2013). Pengantar Ilmu Hukum. Jakarta: Prenadamedia Grup.

Prihatiningtyas, W. (2017). Fungsi Gubernur dalam Penyelenggaraan Pemerintahan di Daerah. Airlangga Development Journal, 1(1), 42-70. Retrieved from https://www.e-
journal.unair.ac.id/ADJ/article/view/18011

Ridwan, H. R. (2008). Hukum Administrasi Negara. Jakarta: Rajawali Press.

Sadjijono. (2008). Memahami Beberapa Bab Pokok Hukum Administrasi. Yogyakarta: LaksBang PRESSindo.

Soekanto, S., \& Mamudji, S. (2001). Penelitian Hukum Normatif: Suatu Tinjauan Singkat. Jakarta: PT. Raja Grafindo Persada.

Suparta, I. K. (2013). Pengawasan terhadap Pramuwisata di Provinsi Bali. Jurnal Magister Hukum Udayana (Udayana Master Law Journal), 2(1). Retrieved from https:// ojs.unud.ac.id/index.php/jmhu/article/ view/4702

Susanto, S. N. H. (2019). Karakter Yuridis Sanksi Hukum Administrasi: Suatu Pendekatan Komparasi. Administrative Law \& Governance Journal, 2(1), 126-142. Retrieved from https:// ejournal2.undip.ac.id/index.php/alj/article/ view/5073

UNWTO. (1977). Internasional Tourism: A Global Perspective. Madrid: The World Tourism Organization.

Webinar, 2020, Menyonsong Normalitas Kehidupan Yang Baru Pasca Covid-19, Badan Penelitian dan Pengembangan Kabupaten Badung, Zoom Video Conference, 27 Mei 2020. 